\section{Evaluation of Chemical Control Methods of Fountain Grass}

\author{
Joseph Thomas ${ }^{1}$ and Matthew Taylor ${ }^{1}$
}

AdDitional InDEX wORDs. fluazifop, glyphosate, herbicide, Pennisetum alopecuroides, sethoxydim

Summary. Fountain grass (Pennisetum alopecuroides) is a common ornamental grass because of its glossy foliage and showy inflorescence. However, there have been reports of populations growing outside of cultivation and demonstrating invasive tendencies. There is limited research of the chemical control of fountain grass in natural areas. The objective of this experiment was to evaluate the impact of glyphosate, sethoxydim, and fluazifop on fountain grass. Treatments consisted of

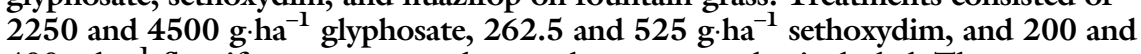
$400 \mathrm{~g} \cdot \mathrm{ha}^{-1}$ fluazifop; a nontreated control group was also included. The percent herbicide injury was determined visually $1,3,4,6$, and 10 weeks after treatment (WAT). Both rates of glyphosate resulted in $100 \%$ of the foliage injured by 3 WAT. The application of flauzifop and sethoxydim led to intermediate results ranging from $15 \%$ to $23 \%$ injury by 6 WAT, with no significant difference between active ingredients or rates. Nontreated control plants exhibited little to no injury throughout the study. Flauzifop, sethoxydim, and glyphosate all caused visible injury to fountain grass. For complete, fast-acting control, glyphosate is recommended. Herbicide control coupled with restorative plantings of native plants can help reduce invasive plant pressure and improve biodiversity of natural areas.

$\mathrm{F}$ ountain grass (Pennisetum alopecuroides) is a warm season, perennial, bunch grass of Asian and Australian origin (Mastalerz, 2012). Fountain grass has glossy, bright green foliage, with some cultivars displaying other coloration (Greenlee and Fell 1992). The inflorescence (Fig. 1) is quite showy, with seed heads ranging from 10 to $25 \mathrm{~cm}$ in length (Greenlee and Fell, 1992; Mastalerz, 2012). Flowers begin as pale white, brown, or pink and mature to reddish brown or purple; they bloom in late summer, with seed heads lasting well into the winter (Greenlee and Fell, 1992). Fountain grass grows in plant hardiness zones 5 through 7 (Lucas, 2011;

Received for publication 31 Dec. 2020. Accepted for publication 18 Feb. 2021

Published online 28 June 2021.

${ }^{1}$ Longwood Gardens, P.O. Box 501, Kennett Square, PA 19348

This paper was presented as part of a workshop titled "Progress in Identification and Control of Weedy to Invasive Plants Both Domestic and Abroad" during the 2020 American Society for Horticultural Science (ASHS) Annual Conference, which was conducted virtually 10-13 Aug. 2020.

M.T. is the corresponding author. E-mail: mtaylor@ longwoodgardens.org.

This is an open access article distributed under the CC BY-NC-ND license (https://creativecommons. org/licenses/by-nc-nd/4.0/).

https://doi.org/10.21273/HORTTECH04789-20
Mastalerz, 2012). Although fountain grass grows best in sunny areas with good drainage, some selections can survive in hotter and drier environments (Lucas, 2011; Mastalerz, 2012). All these attributes make fountain grass a popular plant for ornamental gardening. Many cultivars of this species exist, with the most common being Hameln and Moudry (Lucas, 2011).

Fountain grass is not generally considered an invasive species. However, there have been reports of populations of fountain grass observed growing outside of cultivation in Pennsylvania (specifically Chester and Berks counties), New York, Illinois, and Arkansas (Mastalerz, 2012; Smith and Lipscomb, 1975) (Fig. 1). Darke (1999) reported that 'Moudry' fountain grass can seed heavily into lawns, is particularly fertile, and can be invasive. Voigt and Reicher (2009) further reported that 'Moudry' will prolifically self-seed, and there is evidence that the cultivar does outcross to create new, genetically unique individuals. Quickly identifying plants that demonstrate invasive tendencies and successful management techniques, also described as early detection and rapid response, are core components of invasive species management (Miller et al., 2015; Reaser et al., 2020). Horticulture professionals are ideally situated to observe newly introduced species and be alert for species of concern.

Although there are reports of fountain grass seeding into natural areas and being considered invasive, chemical control has not been thoroughly studied. Several studies have evaluated grass-specific herbicides. Catanzaro et al. (1993) indicated that fountain grass exhibited severe $(>74 \%)$ phytotoxicity $69 \mathrm{~d}$ after treatment (DAT) with fenoxaprop, fluazifop, quizalofop, or sethoxydim at $1 \times$ and $2 \times$ the commercial formulation rates. Fluazifop caused the greatest injury of $98 \%$ and $99 \%$ at respective rates. Gilliam et al. (1992) treated 'Hameln' fountain grass with fenoxaprop-ethyl, fluazifop, or sethoxydim at 0.28 or $0.56 \mathrm{~kg} \cdot \mathrm{ha}^{-1}$ and observed moderate visual injury 30 DAT and a significant reduction in inflorescence number 60 DAT compared with the untreated control. The two previous studies involved plants growing in containers. Hubbard and Whitwell (1991) evaluated the same herbicides as Gilliam et al. (1992) did at $0.4 \mathrm{~kg} \cdot \mathrm{ha}^{-1}$ on fountain grass that was field-grown. At $70 \mathrm{DAT}$, plants treated with fluazifop had the greatest percentage of injury at $57 \%$, whereas other herbicide treatments resulted in only $10 \%$ injury. Voigt and Reicher (2009) evaluated several grass-specific herbicides at label rates alone and in combination and found that two applications of fluazifop and triclopyr mix were highly injurious to fountain grass, but not lethal. Both herbicides were much less effective when applied alone; however, even in combination, they did not control fountain grass as well as the nonselective herbicide glyphosate, which provided complete control at both 28 and 56 DAT.

\begin{tabular}{llll}
\hline $\begin{array}{l}\text { Units } \\
\begin{array}{l}\text { To convert U.S. to SI, } \\
\text { multiply by }\end{array}\end{array}$ & U.S. unit & SI unit & $\begin{array}{l}\text { To convert SI to U.S., } \\
\text { multiply by }\end{array}$ \\
\hline 0.0929 & $\mathrm{ft}^{2}$ & $\mathrm{~m}^{2}$ & 10.7639 \\
2.54 & inch(es) & $\mathrm{cm}$ & 0.3937 \\
1.1209 & $\mathrm{lb} / \mathrm{acre}$ & $\mathrm{kg} \cdot \mathrm{ha}^{-1}$ & 0.8922 \\
70.0532 & $\mathrm{oz} / \mathrm{acre}$ & $\mathrm{g} \cdot \mathrm{ha}^{-1}$ & 0.0143
\end{tabular}




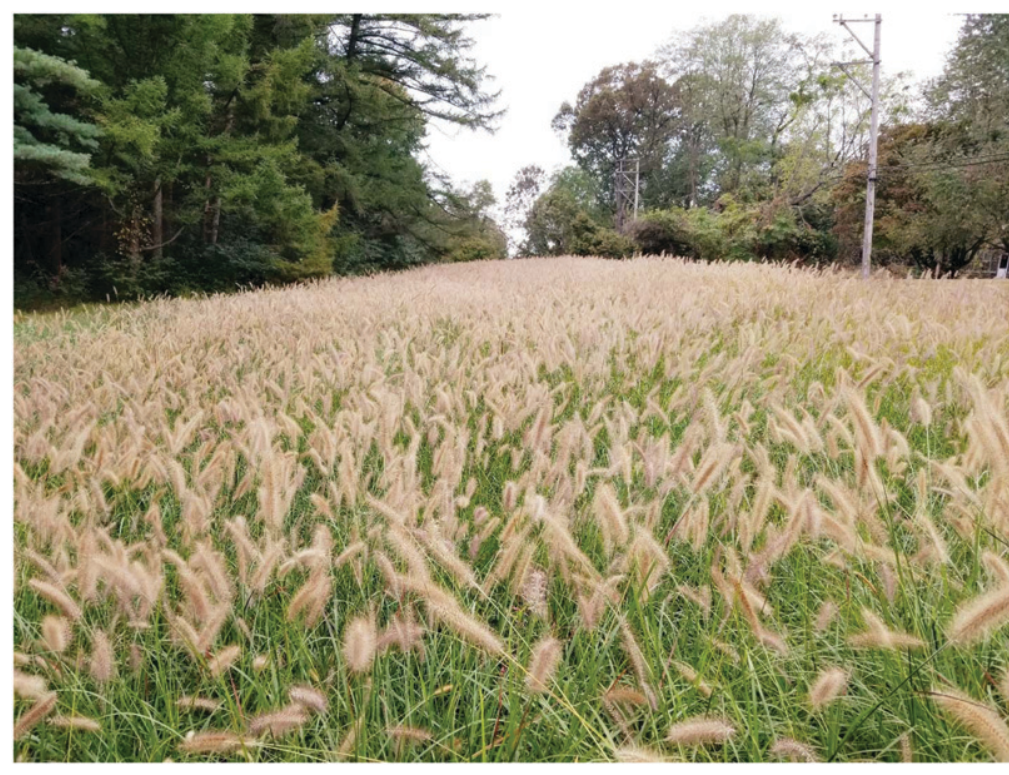

Fig. 1. Natural area completely invaded by fountain grass and the site of the experiment described in this article. Plants have slightly darker foliage and darker inflorescence than the straight species, and they may be progeny from 'Moudry' fountain grass.

All previous research was performed in controlled outdoor plots or in containers during greenhouse studies. The objective of this experiment was to evaluate the impact of glyphosate, sethoxydim, and fluazifop on fountain grass that invaded a meadow area to a near-monoculture.

\section{Materials and methods}

The site for this experiment was Longwood Gardens in Kennett Square, PA (lat. $39^{\circ} 52^{\prime} 40.0^{\prime \prime} \mathrm{N}$, long. $\left.75^{\circ} 4 \mathrm{l}^{\prime} 03.0^{\prime \prime} \mathrm{W}\right)$. The experimental area is between a state route and a stand of pines (Pinus sp.), and it is slightly southerly sloped. The area would usually receive some road salt in the winter months because of snowfall in the area and proximity of the state route. The area has been invaded by fountain grass for at least 5 years and was nearly monotypic. Plants have slightly darker foliage and darker inflorescence than the straight species, and they may be progeny from 'Moudry' fountain grass; however, this has not been verified (Fig. 1).

Treatments consisted of 2250 and $4500 \mathrm{~g} \cdot \mathrm{ha}^{-1}$ glyphosate (Ranger Pro; Monsanto, St. Louis, MO), 262.5 and $525 \mathrm{~g} \cdot \mathrm{ha}^{-1}$ sethoxydim (Segment; BASF Corp., Research Triangle Park, NC), and 200 and $400 \mathrm{~g} \cdot \mathrm{ha}^{-1}$ fluazifop (Fullisade DX; Syngenta Crop Protection, Greensboro, NC); a nontreated control was also included. The nontreated check was not altered in any way during treatment. Higher rates were selected based on label recommendations for use of the product on natural lands for species similar to fountain grass, and lower rates were half of the higher rates.

The experimental area was 34,368 $\mathrm{ft}^{2}$ and divided into 21 plots $100 \mathrm{ft}^{2}$ in size. To reduce edge effects and facilitate observation, each experimental plot was flagged at each corner and surrounded on all sides with a 6-inch buffer. Each treatment was replicated three times and arranged in a randomized complete block design. Pine trees to the south of the experimental plot cast a shadow over the plots during the winter months; therefore, replications were oriented north to south, with randomized treatments running east to west.

Treatments were applied using a calibrated hand pump sprayer (415; Solo, Newport News, VA) equipped with a flat fan nozzle on 25 July 2019, when the average height of the fountain grass measured $30 \mathrm{~cm}$ from the ground to the top of the foliage. The percent herbicide injury was determined by a trained observer who visually evaluated the approximate percent of fountain grass foliage within the treatment plots exhibiting chlorosis and/or necrosis ranging from $0 \%$ to $100 \%$. Data were collected 1, 3, 4, 6, and 10 WAT. Data were statistically analyzed as a complete block design, with all interactions considered significant at $P=0.05$. The herbicide treatment $\times$ WAT interaction was significant; therefore, data are presented over time. Error bars presented in the figures were determined using the SE function of SigmaPlot (Systat Software, San Jose, CA).

\section{Results and discussion}

Both rates of glyphosate resulted in $100 \%$ of the foliage injured by 3 WAT (Fig. 2). At and beyond 3 WAT, all aboveground plant material was necrotic in plots treated with either rate of glyphosate. Flauzifop and sethoxydim application led to intermediate results ranging from $15 \%$ to $23 \%$ injury to fountain grass foliage by 6 WAT, with no significant difference between these two products or rates. The plants in control treatments exhibited little to no injury throughout the study. Spacing between plots and application during appropriate conditions reduced the possibility of spray drift. The percent visual injury recorded for nontreated plots was of an unknown cause.

Results of this study were similar to those of previous research evaluating grass-specific herbicides on fountain grass grown in containers (Catanzaro et al., 1993; Gilliam et al., 1992) and in the field (Hubbard and Whitwell, 1991), where fluazifop and sethoxydim application led to intermediate control that never reached $100 \%$. Further research is needed to determine if multiple applications over a single growing season or over multiple seasons can provide complete control. An additional factor that may impact the effectiveness is the addition of a surfactant, which was used during two of the previous studies (Catanzaro et al., 1993; Gilliam et al., 1992), but not consistently, across treatments or as an experimental factor.

Full elimination of fountain grass with grass-specific herbicides can be especially important in natural areas that have been partially invaded and have a strong presence of native forbs. Fluazifop is not currently labeled for use in natural areas. However, $\mathrm{Tu}$ et al. (2001) indicated that fluazifop was an effective chemical for controlling several different invasive grasses in natural areas. Alternatives to chemical control for fountain grass are limited. Biological control agents for fountain grass do not exist, and the 


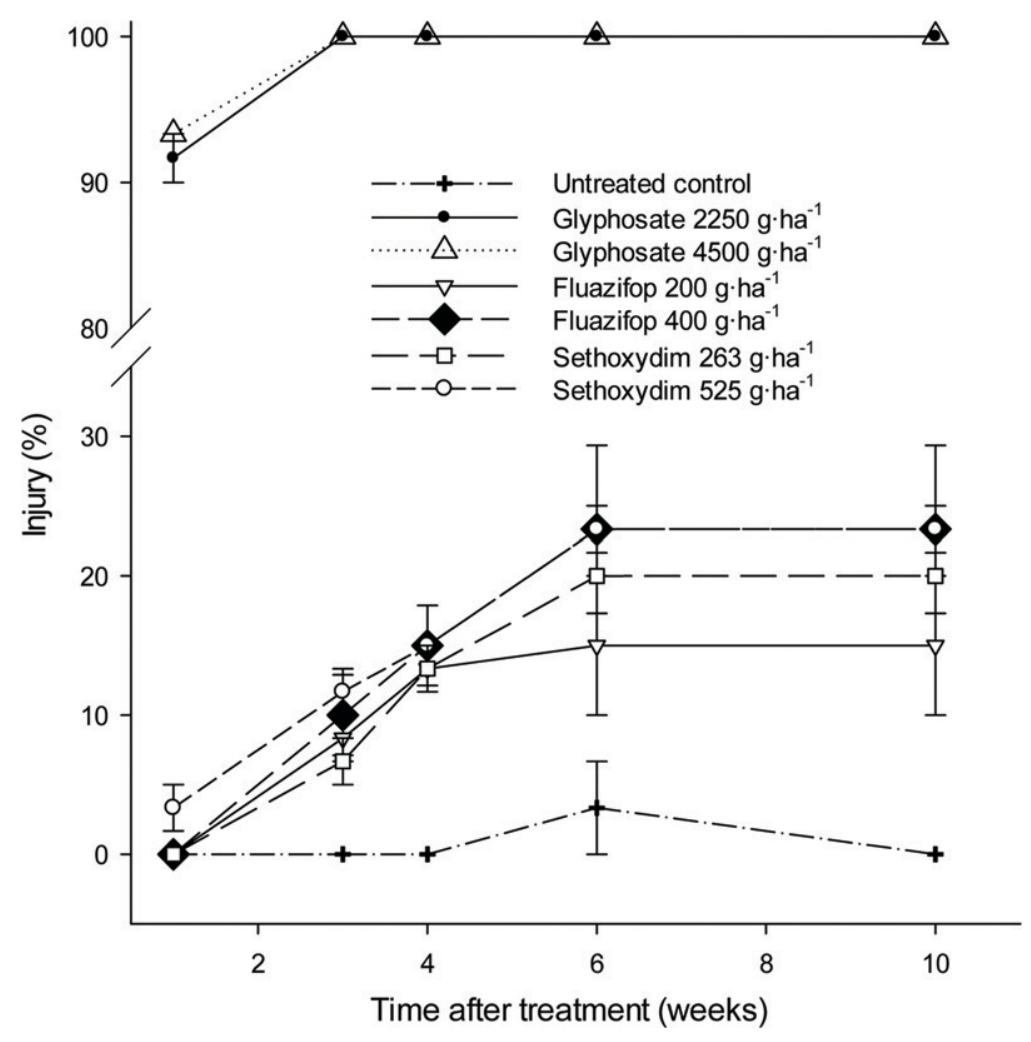

Fig. 2. Foliar injury of fountain grass $1,3,4,6$, and 10 weeks after treatment with two rates of glyphosate, flauzifop, or sethoxydim and an untreated control. Error bars represent $\mathrm{SE}(\mathrm{n}=3) ; 1 \mathrm{~g} \cdot \mathrm{ha}^{-1}=0.0143 \mathrm{oz} /$ acre.

development of a biological control option is highly unlikely because of its common use as an ornamental plant (Mastalerz, 2012). Fountain grass also has no natural pest issues (Greenlee and Fell, 1992). Mechanical removal is difficult, laborious, and leads to significant soil disturbance.

When monotypic stands of fountain grass have been established or spot treatment is feasible, glyphosate application can be an effective management tool. This experiment and the work of Voigt and Reicher (2009) showed that $100 \%$ of the foliage was injured by 4 WAT when glyphosate was applied at the label rate. Furthermore, $100 \%$ foliar damage was observed during this study at half the label rate, thus indicating that lower rates can be as effective.

When natural areas and native plant communities have been invaded by fountain grass, integrated approaches should be used for eradication. Flauzifop, sethoxydim, and glyphosate, along with other vegetation management techniques, such as mowing and handremoval of seed heads, are all tools for controlling spread and eliminating populations. For fast-acting control, spot treatments of glyphosate at the full or half the label rate are recommended, ideally before seed set. Coupled with restorative plantings of native plants, eliminating fountain grass from natural areas reduces invasive plant pressure and improves biodiversity.

\section{Literature cited}

Catanzaro, C.J., W.A. Skroch, and J.D. Burton. 1993. Resistance of selected ornamental grasses to graminicides. Weed Technol. 7(2):326-330.

Darke, R. 1999. The color encyclopedia of ornamental grasses: Sedges, rushes, restios, cat-tails and selected bamboos. Timber Press. Portland, OR.

Gilliam, C.H., G.J. Keever, D.J. Eakes, and D.C. Fare. 1992. Postemergence applied herbicides for SSE on ornamental grasses. J. Environ. Hort. 10(3):136-139.

Greenlee, J. and D. Fell. 1992. The encyclopedia of ornamental grasses: How to grow and use over 250 beautiful and versatile plants. Rodale Press. Emmaus, PA.

Hubbard, J. and T. Whitwell. 1991. Ornamental grass tolerance to postemergence grass herbicides. HortScience 26 (12):1507-1509.

Lucas, N. 2011. Designing with grasses. Timber Press. Portland OR.

Mastalerz, A. 2012. Invasive plant alert: Fountain grass (Pennisetum alopecuroides (L.) Spreng.). Natl. Park Serv., Natl. Capital Reg. Exotic Plant Manag. Team, Washington, DC.

Miller, J.H., S.T. Manning, and S.F. Enloe. 2015. A management guide for invasive plants in southern forests. U.S. Dept. Agr., For. Serv., Gen. Tech. Rep. SRS-131.

Reaser, J.K., S.W. Burgeil, J. Kirkey, K.A. Brantley, S.D. Veatch, and J. BurgosRodríguez. 2020. The early detection of and rapid response (EDrR) to invasive species: A conceptual framework and federal capacities assessment. Biol. Invasions 22(1):1-19.

Smith, S.B. and B.L. Lipscomb. 1975. Some new or otherwise noteworthy plants of the Arkansas flora. J. Ark. Acad. Sci. 29:65.

Tu, M., C. Hurd, and J.M. Randall. 2001. Weed control methods handbook: Tools \& techniques for use in natural areas. Paper 533. Nature Conservancy, Arlington, VA.

Voigt, T.B. and Z.J. Reicher. 2009. Selectively controlling escaped fountain grass in cool-season turf. Appl. Turfgrass Sci. 6(10):1094. 